\title{
A IMPORTÂNCIA DA LÍNGUA PORTUGUESA NA ÁREA DE ADMINISTRAÇÃo
}

\author{
MARTINS, Vera Lucia Bianchini \\ MONTEIRO, Jucilene A. Arruda
}

\section{INTRODUÇÃO}

Interessados em chamar a atenção dos professores, dos profissionais de Comunicação e dos estudantes sobre a real importância da Língua Portuguesa, os estudiosos do assunto têm realizado, no Brasil, vários estudos, seminários e encontros, sendo que, em 1999, foi realizado pela Academia Brasileira de Letras $(A B L)$, em conjunto com o Centro de Integração Empresa Escola (CIEE), um seminário sobre os desafios e soluções referentes à Língua Portuguesa, o qual teve a participação de acadêmicos ilustres como Lygia Fagundes Teles e o Presidente da ABL, Sr. Arnaldo Niskier.

Em uma pesquisa efetuada pelo CIEE, foi constatado que $70 \%$ dos alunos de Administração baseiam sua formação em apostilas reproduzidas na própria faculdade. Vários jornais têm mostrado essa preocupação. A Folha de São Paulo evidenciou, em muitas de suas reportagens, que o estudante universitário lê pouco e, quando lê, tende a se limitar às apostilas, aos resumos e aos capítulos xerocopiados dos livros.

$\mathrm{Na}$ maioria das vezes, há também uma grande deficiência em redação, envolvendo tanto os erros gramaticais quanto a deturpação e deformação de conceitos e fatos. 
No intuito de auxiliar os estudantes e profissionais de administração e ainda criar subsídios para a mudança desse perfil é que este trabalho foi realizado. Ele possui como objetivo principal conscientizar os profissionais da área de administração sobre a importância da correta utilização da língua materna em seu cotidiano, aspecto este que influencia não só a imagem da empresa em que atua, como também a sua própria imagem como profissional e cidadão brasileiro.

Para tanto, foram desenvolvidos de maneira lógica e objetiva, os seguintes tópicos:

A Língua Portuguesa nos processos de recrutamento, seleção, admissão, treinamento e demissão;

$>$ A Língua Portuguesa x Imagem x Qualidade Total;

> A importância da adequada abordagem nas redações comerciais;

A linguagem como fator de venda de imagem.

Morin (1995, p. 81), citado por Maria Cândida Moraes no livro O Paradigma Educacional (1999, p. 72), afirma: "Eu considero impossível conhecer as partes sem conhecer o Todo, assim como conhecer o Todo sem conhecer particularmente as partes". É uma concepção sistêmica. A partir desse conceito, chega-se à conclusão de que existe um sistema (para este trabalho, a empresa). Esse sistema é formado por partes que se integram e se complementam entre si (setores, departamentos e colaboradores).

O sistema como um todo é representado por suas partes individualmente ou em conjunto, ou seja, a sua imagem dependerá dessas partes e o impacto externo será determinado pela atuação das partes. Sendo assim, pode-se ilustrar o pensamento acima com o diagrama a seguir: 
Revista Eletrônica de Ciência Administrativa (RECADM) - ISSN 1677-7387

Faculdade Cenecista de Campo Largo - Coordenação do Curso de Administração

v. 1, n. 1, maio/2003 - http://revistas.facecla.com.br/index.php/recadm/

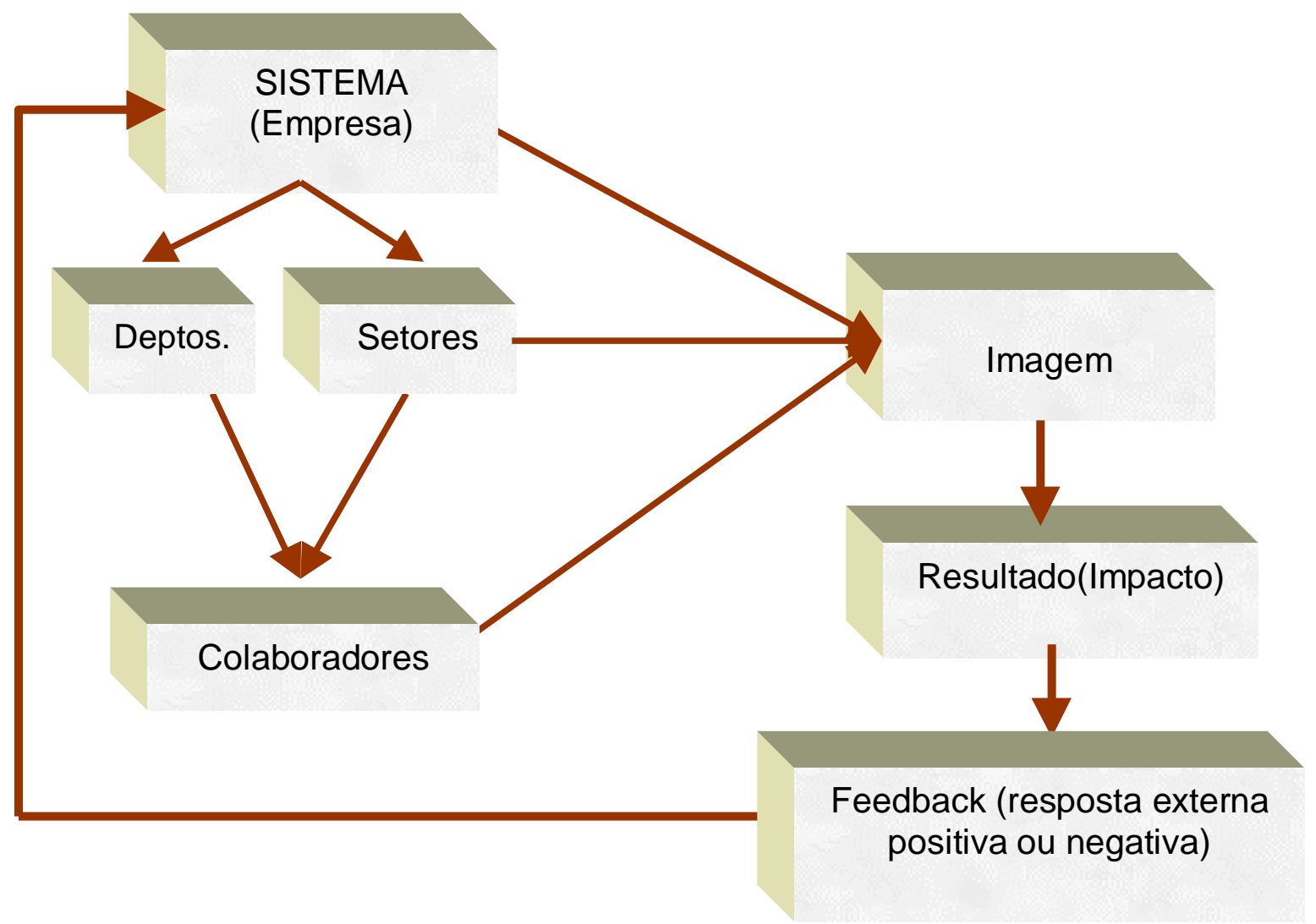




\section{A Língua Portuguesa nos Processos de Recrutamento, Seleção, Treinamento, Admissão e Demissão}

Sabe-se que, na administração de uma empresa, a comunicação é extremamente importante uma vez que todas as informações no âmbito organizacional devem ser transmitidas com clareza e objetividade, de modo que não gerem dúvidas aos receptores das mensagens.

Especificamente no que tange à Administração de Recursos Humanos, percebe-se a grande e peculiar importância da língua materna.

O recrutamento de pessoal consiste em procedimentos pelos quais a empresa tem como objetivo atrair a mão-de-obra de que necessita.

Isso pode ser feito por intermédio de diversas fontes, tais como: escolas, agências de emprego, anúncios em jornais, rádio, televisão, internet e similares. Um dos meios mais utilizados para atrair candidatos são os anúncios efetuados pela imprensa escrita, devido à sua praticidade. Entretanto, a redação do anúncio deve ser clara e conter informações essenciais para atrair os candidatos mais desejáveis. Para tanto, a pessoa do anunciante deverá demonstrar domínio de vocabulário, utilizar-se de palavras e frases dispostas corretamente, evitando, dessa forma, a disseminação de dúvidas e incoerências na mensagem.

Segundo o Prof. Eli Rozendo (1980, p. 35), a linguagem é uma fonte de muitas falhas na comunicação, e o desconhecimento do significado correto de uma palavra por parte do receptor pode levar à incompreensão e ao fracasso de toda a mensagem. De outra forma, se o emissor faz uso de uma palavra sem ter certeza do seu significado, pode produzir uma mensagem inteiramente diferente da que deseja transmitir. 
Ainda no que se refere ao processo de recrutamento, a maneira como a mensagem for transmitida será a responsável pelos candidatos advindos dessa procura, sendo que uma mensagem clara e objetiva atrairá candidatos realmente "atinentes" ao cargo em questão, enquanto que, se a mensagem gerar dúvidas devido à incoerência ou à falta de objetividade, poderá atrair candidatos com perfis profissionais alheios aos que o cargo necessita. Tal fato causaria perda de tempo e transtornos, o que poderia ser evitado com a correta utilização da Língua Portuguesa, com um vocabulário adequado e com palavras bem empregadas e frases bem formuladas.

O mesmo raciocínio deverá ser utilizado nos processos de seleção, treinamento, admissão e demissão de empregados, ou seja, faz-se necessário um cuidado especial na transmissão de mensagens oriundas dos processos de comunicação organizacional, sejam essas mensagens transmitidas de forma oral ou escrita, a fim de que não causem dúvidas, transtornos e/ou constrangimentos para ambas as partes (empregado e empregador), pois a forma como essa mensagem é transmitida, poderá, também, influenciar negativa ou positivamente a imagem da organização.

\section{Língua Portuguesa x Imagem x Qualidade Total}

Vive-se, atualmente, em busca da qualidade total em produtos e serviços. Pode-se deduzir, então, que uma empresa que objetiva alcançar a qualidade total não poderá transmitir uma imagem negativa a seus clientes, ou seja, esse tipo de impacto poderá causar à sua clientela uma rejeição por seus produtos e/ou serviços. 
Pode-se assim concluir que há uma ligação intrínseca entre a imagem da empresa e a busca da qualidade total dessa organização.

A Língua Portuguesa como um todo está amplamente ligada a esses dois fatores, já que há uma relação de interdependência entre ela e a imagem, no que concerne às mensagens escritas e orais emitidas pela empresa.

A mensagem será causadora de um impacto em todos que a receberem. Esse impacto (positivo ou negativo) refletirá a imagem da organização.

Sendo assim, a imagem da empresa depende de seus dirigentes e colaboradores. Afinal, como explicar um diretor escrevendo em uma carta comercial: "se houverem perspectivas", "estou enviando", "a reclamação foi efetuada junto ao órgão competente" ou "a nível de..." ou mesmo verbalizando tais expressões? Fica aqui um questionamento: Que imagem esse diretor transmitirá da empresa ou do setor em que trabalha? Será a imagem de alguém preparado para o mercado atual, tão exigente quanto ao "ouro" maior chamado conhecimento?

Segundo Frank M. Corrado, em seu livro A Força da Comunicação (1994, p. 13), a comunicação pode causar um impacto direto no resultado final - para melhor ou para pior. Salienta, ainda, que quatro de cada cinco executivos principais acreditam "de verdade" que seus esforços de comunicação podem realmente causar esse impacto. Dessa forma, há que se oferecer caminhos mais acessíveis para o aprendizado da Língua Portuguesa em seus diversos aspectos: gramática, interpretação de textos, redação e outros pertinentes ao estudo da língua materna. Só assim as empresas serão capazes de gerar e transmitir comunicações claras e objetivas em seus vários níveis hierárquicos, interna ou externamente, evitando equívocos e construindo uma imagem positiva no mercado em que atuam. 


\section{A Importância da Adequada Abordagem nas Redações Comerciais}

A redação é item de extrema importância em uma organização, sendo a sua correta abordagem fator fundamental para o entendimento da mensagem final.

A redação de cartas comerciais, ofícios, memorandos, atas, relatórios, acordos, requerimentos, circulares, contratos e similares fazem parte do cotidiano das organizações, sejam elas, pequenas, médias ou grandes empresas.

Nos dias atuais, escrever com clareza, coerência e concisão é uma vantagem competitiva capaz de elevar a imagem da empresa perante a sua clientela, os seus colaboradores, os seus fornecedores e, também, perante a concorrência. Trata-se de uma competência especial na comunicação, uma preocupação em fazer o melhor, produzir produtos e prestar serviços que tenham arraigados em si um patrimônio cultural que é a Língua Portuguesa, na clareza e objetividade dos textos, na gramática correta, na certeza de que a mensagem transmitida não será geradora de dúvidas, e sim de uma interpretação certeira.

Para uma boa redação há que se ter argumentação adequada e convincente, além de precisão e assertividade vocabular, criatividade, coerência e, ainda, conhecimento do assunto em questão. Devem ser evitadas as falhas gramaticais, as gírias, as pontuações inadequadas, os pleonasmos, os estrangeirismos, as expressões vagas ou ambíguas, além de outros empecilhos que possam influir na precisão dos resultados esperados com a veiculação de tal mensagem.

De acordo com João Bosco Medeiros (1995, p. 47), pensar antes de falar e refletir antes de escrever são regras fundamentais para a comunicação eficaz. 
Para Medeiros (1995, p.77), a redação comercial exige a mesma atenção que se dedicaria a um texto literário ou a um relatório técnico. Não é com agastamento, cansaço ou aborrecimento que se transmite uma imagem positiva da empresa; também não se conquista a atenção do leitor com uma linguagem pejada de estrangeirismos, e cuja estruturação frasal seja confusa.

Torna-se, portanto, necessária por parte dos administradores a plena consciência de que a imagem da empresa em seu mercado de atuação é fator que depende intrinsecamente da maneira pela qual a organização se comunica e expressa a sua mensagem.

\section{A Linguagem como fator de Venda de Imagem}

Para Maria Luiza Abaurre et alli, em seu livro Português, Língua e Literatura (2000, p. 2), a linguagem é decorrente de práticas sociais de uma cultura humana, representando-as e modificando-as, sendo o seu exercício atividade predominantemente social. Salienta, ainda, que as linguagens desenvolvidas pelo Homem pressupõem conhecimento, por parte de seus usuários, do valor simbólico dos seus signos.

A partir dessa concepção de linguagem, pode-se atribuir a ela uma grande influência na imagem de um produto ou serviço.

A maneira como a linguagem é exposta determina o público a ser atingido, isto é, a linguagem deverá estar de acordo com o público-alvo.

A linguagem utilizada por uma organização na venda de produtos ou serviços será um dos fatores responsáveis pelo sucesso ou insucesso de tais atividades. 
Compreende-se assim que o consumidor desses produtos ou serviços continuamente estará relacionando-os à linguagem outrora utilizada para induzi-lo a adquirir tais bens. Se não for uma linguagem adequada, inteligível para o receptor, a recepção da mensagem poderá ser causadora de equívocos e até de desinteresse pelo produto ou serviço oferecido.

Ainda segundo Abaurre et alli (2000, p. 4), a linguagem é antes de tudo uma atividade do sujeito, um lugar de interação entre os membros de uma sociedade, que podem usá-la tanto para revelar como para esconder suas verdadeiras intenções, visto que, por ser indeterminada a linguagem permite a ambigüidade e os duplos sentidos.

Nas empresas, há que se tomar um cuidado especial em aspectos referentes à ambigüidade da linguagem, pois da direção enfocada pela mensagem dependerá o sucesso ou não do que se deseja transmitir. Estará em pauta não só a imagem do produto ou serviço, bem como a imagem da empresa como um TODO inserido em uma comunidade capaz de responder negativa ou positivamente, comunidade esta composta por clientes, colaboradores, fornecedores e a sociedade em geral. Tais respostas poderão proporcionar à organização uma atuação medíocre ou uma atuação brilhante. Sem dúvida alguma, os representantes da empresa, em seus diversos aspectos, serão responsáveis pela qualidade dos produtos e serviços oferecidos, o que inclui esta vantagem competitiva, este diferencial que é a linguagem adequada de acordo com os moldes e preceitos da língua materna. 


\section{PESQUISA}

O questionário de pesquisa, denominado Pesquisa sobre a Importância da Língua Portuguesa nas Organizações, composto de cinco questões foi aplicado a vinte e um participantes, sendo que para esse universo pesquisado, nove pessoas são do sexo masculino e doze pessoas são do sexo feminino, com profissões diversas, entre elas: administradores; contabilistas; médicos; professores; estudantes de curso superior de administração, de comunicação social e de letras; bibliotecários, auxiliar de enfermagem e outros.

A aplicação do questionário deu-se em duas cidades distintas: Campo Grande, situada no estado de Mato Grosso do Sul, região Centro-Oeste do Brasil, e Curitiba, localizada no estado do Paraná, região Sul do país. O fato de a pesquisa ter sido realizada nestas cidades agregou, com certeza, maior credibilidade ao trabalho ora desenvolvido, pois de maneira dinâmica, conseguiu-se abranger resultados de dois estados com culturas e tradições diferentes. Entretanto, por intermédio de tais resultados, percebeu-se que há um consenso no que diz respeito ao impacto negativo que enganos, erros e distorções na comunicação escrita ou oral podem proporcionar a uma empresa e a seus dirigentes, influenciando de maneira direta e indireta a imagem da organização como um todo. 
Revista Eletrônica de Ciência Administrativa (RECADM) - ISSN 1677-7387

Faculdade Cenecista de Campo Largo - Coordenação do Curso de Administração

Abaixo, a tabulação do questionário aplicado na referida pesquisa.

1) Marque as alternativas que, na sua opinião, sejam mais adequadas ao caso:

$O$ dirigente (diretor ou presidente) empresarial que fala ou escreve errado - sem demonstrar preocupação com a correta utilização do idioma - é, na sua opinião:

\begin{tabular}{|l|c|c|}
\hline \multicolumn{1}{|c|}{ ALTERNATIVAS } & № DE PESSOAS & PERCENTUAL \\
\hline $\begin{array}{l}\text { uma pessoa despreparada no que diz respeito ao idioma } \\
\text { do país em que vive. }\end{array}$ & 05 & $23,81 \%$ \\
\hline uma pessoa interessada em aprender. & 0 & 0 \\
\hline $\begin{array}{l}\text { alguém que transmite uma imagem positiva da empresa } \\
\text { em que atua. }\end{array}$ & 0 & 0 \\
\hline $\begin{array}{l}\text { alguém que transmite uma imagem negativa da empresa } \\
\text { em que atua. }\end{array}$ & 7 & $33,33 \%$ \\
\hline $\begin{array}{l}\text { um indivíduo atualizado com as exigências do mercado de } \\
\text { trabalho. }\end{array}$ & 0 & 0 \\
\hline $\begin{array}{l}\text { uma pessoa despreparada no que diz respeito ao idioma } \\
\text { do país em que vive e, também, alguém que transmite } \\
\text { uma imagem negativa da empresa em que atua. }\end{array}$ & 09 & $42,86 \%$ \\
\hline TOTAL & 21 & $100 \%$ \\
\hline
\end{tabular}

Gráfico llustrativo das respostas dadas pelos participantes à primeira questão do questionário aplicado.

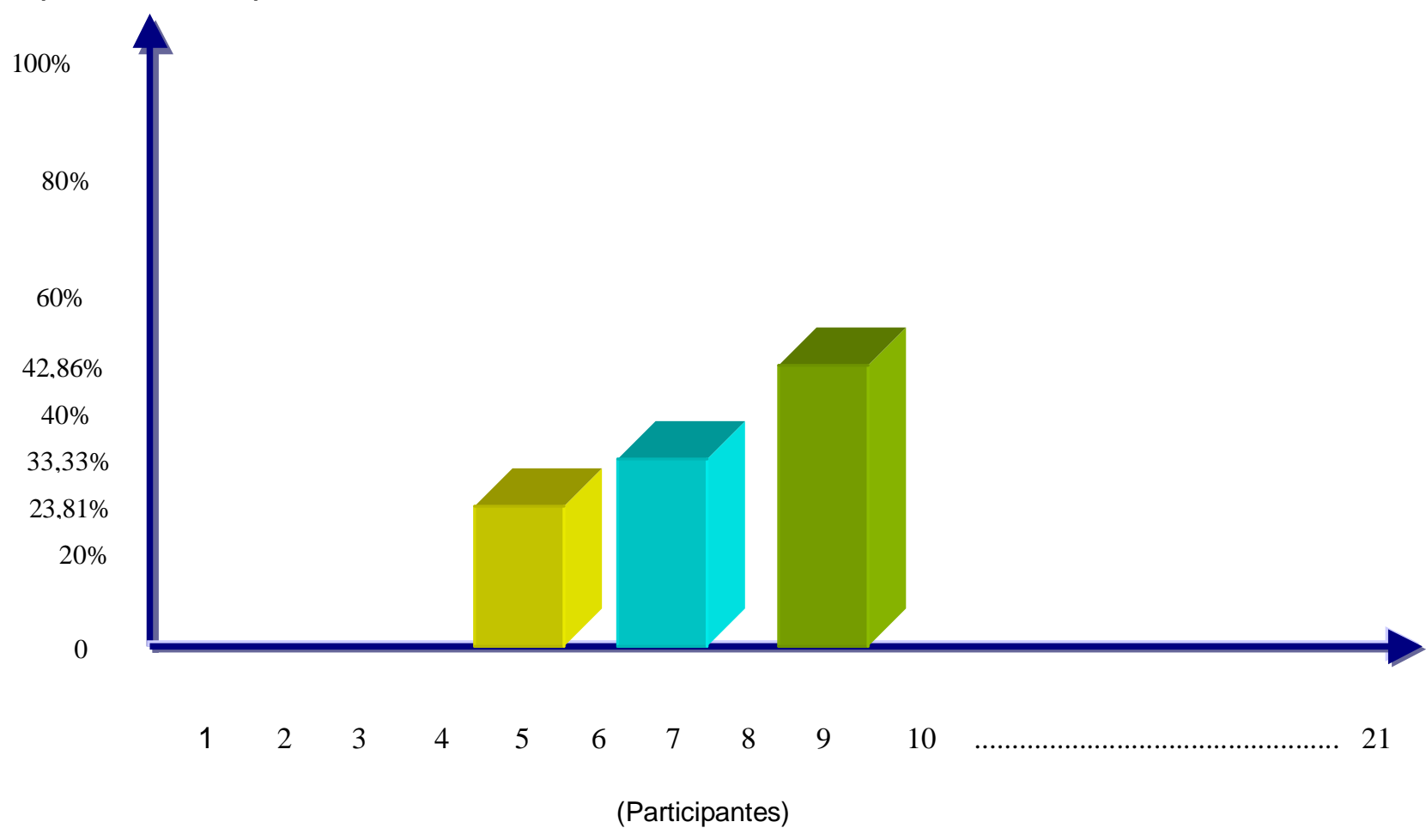




\section{Legenda:}

Número de participantes que responderam ser o dirigente (diretor ou presidente) da empresa uma pessoa despreparada no que diz respeito ao idioma do país em que vive: 5 participantes, o que equivale a $23,81 \%$ dos pesquisados.

Número de participantes que responderam ser o dirigente (diretor ou presidente) da empresa alguém que transmite uma imagem negativa da organização em que atua: 7 participantes, o que equivale a 33,33\% dos entrevistados.

Número de participantes que responderam ser o dirigente (diretor ou presidente) da empresa uma pessoa despreparada no que diz respeito ao idioma do país em que vive e, também, alguém que transmite uma imagem negativa da organização em que atua: 9 participantes, o que equivale a $42,86 \%$ dos profissionais pesquisados.

2) Compare os textos dos anúncios abaixo. Qual deles retrata com maior clareza e positividade a imagem da empresa e é também, mais objetivo em relação ao profissional que deseja contratar?

\begin{tabular}{|c|c|}
\hline ANÚNCIO 1 & ANÚNCIO 2 \\
\hline $\begin{array}{l}\text { VENDEDOR - Esquadria, comparecer Av. Raquel } \\
\text { de Queiroz no } 1330 \text {. Serralheria e Vidraçaria. } \\
381.2941 .\end{array}$ & $\begin{array}{l}\text { SERRALHERIA Precisa de pessoas dinâmicas, } \\
\text { com garra, que gostem de lidar com o público e que } \\
\text { possuam condução própria para trabalhar com } \\
\text { vendas de esquadrias. Não é necessário ter } \\
\text { experiência anterior. Fornecemos treinamento. } \\
\text { Comparecer na Rua } 15 \text { de Novembro, } 125 \text { - centro, } \\
\text { das 08:00 às } 14: 00 \mathrm{~h} \text { e falar com Sr. Kléber. }\end{array}$ \\
\hline
\end{tabular}

Fonte - Adaptação: "Diário do Pantanal”-Edição de 25/26 de maio de 2002

Nesta questão houve unanimidade na resposta, ou seja, 100\% dos participantes escolheram o anúncio 2 como sendo o mais objetivo. As justificativas para essa escolha foram variadas: possui mais informações, mostra melhor o perfil do profissional, é mais completo, mais objetivo, melhor redigido, mais claro, mais definido, dentre outras.

3) Você acredita que a clareza, objetividade, gramática e ortografia em uma redação comercial possam influenciar na imagem transmitida pela empresa? Justifique sua resposta.

Nesta questão, também houve unanimidade, isto é, 100\% dos participantes responderam "sim", utilizando-se de diversas justificativas para tal resposta, entre elas, o grau de comprometimento desses itens (clareza, objetividade, gramática e ortografia) com a imagem da empresa e a conseqüente associação desses itens com o produto ou serviço oferecido pela organização.

4) No seu ponto de vista, é importante que as pessoas falem e escrevam corretamente?

Para esta questão, $100 \%$ dos participantes responderam que é importante que as pessoas falem e escrevam corretamente. 
5) Você considera a leitura como um dos fatores importantes no aprendizado da língua e cultura de um país? Justifique sua resposta.

Neste item, houve novamente unanimidade nas respostas - $100 \%$ dos pesquisados consideram a leitura como um dos fatores importantes no aprendizado da língua e cultura de um país. Entre as justificativas para essa crença destacam-se: a facilidade na construção e interpretação de textos, proporcionada pela leitura; a leitura como fonte de conhecimento; o aperfeiçoamento por intermédio da leitura; o "aumento" da cultura e do vocabulário; a facilidade de entendimento; o aperfeiçoamento da cultura e da língua; a ampliação da visão do mundo; a atualização do conhecimento e de novas técnicas no mercado de trabalho; a facilidade na compreensão e resolução de problemas; o crescimento como pessoa e como país demonstra ainda o nível de educação, dentre outras. 


\section{METODOLOGIA}

Para efeito de constatação da importância da Língua Portuguesa na área de Administração, bem como da sua influência na imagem das organizações empresariais, foi realizada uma pesquisa na qual foi utilizada a aplicação de um questionário para um universo de vinte e um participantes, profissionais de diferentes áreas, com escolaridade variável entre o ensino médio e o ensino superior.

Salienta-se que esta pesquisa, advinda de uma pequena amostra, não tem a pretensão de demonstrar resultados definitivos, e sim de promover um alerta aos profissionais em geral e, principalmente, aos profissionais da área de Administração, levando-os à reflexão e à conscientização do poder da língua materna nos processos de comunicação organizacional.

Para o presente trabalho também foram utilizadas concepções de diversos autores e dados estatísticos relacionados à área de estudo. 


\section{CONSIDERAÇÕES FINAIS}

Neste trabalho, foi abordada a importância da Língua Portuguesa para a área de Administração, levando-se em consideração a repercussão da língua no que tange à imagem de uma organização.

Sabe-se que a língua faz parte da cultura de um país, e a sua correta utilização é um dever quase que patriótico.

A língua materna encontra-se em todas as áreas do conhecimento e do saber humano: na troca de idéias sobre determinado assunto, nas negociações, na compra e venda de produtos ou serviços, na roda de amigos, nos bancos acadêmicos, no comércio, na indústria, nas organizações públicas, enfim, em todos os locais onde há seres humanos. Portanto, de forma oral ou escrita, deve ser usada de maneira adequada, deixando clara a mensagem do emissor para o receptor.

Nas empresas, essa clareza é de extrema importância na "arte de ordenar". Segundo Eli Rozendo (1980 p. 48-49), as ordens devem ser claras, coerentes, concisas, precisas, diretas e inequívocas. Dessa maneira, uma ordem oral ou escrita para ser bem compreendida deverá estar em concordância com os preceitos da língua em que foi emitida, no caso estudado neste trabalho, a Língua Portuguesa.

Rozendo (1980, p. 11) destaca também a importância da comunicação em todos os níveis: entre subalternos e superiores, entre empregados e patrões, entre a empresa e o público, entre a empresa e os fornecedores, nos jornais e revistas destinados aos empregados, nas reuniões, nas cartas, nos relatórios, nos gráficos, nos memorandos, nos panfletos e nos filmes publicitários.

Trata-se, portanto, da imagem da empresa como um sistema por meio do qual ela transmitirá a sua mensagem, e a maneira como essa mensagem for transmitida 
poderá resultar uma resposta (feedback) positiva ou negativa oriunda do ambiente externo ou, até mesmo, do ambiente interno. Essa resposta poderá ser a responsável pelo sucesso ou insucesso da organização.

É de vital importância que a organização agregue valor ao seu potencial por intermédio da sua imagem, da sua cultura, da sua interação com clientes e parceiros e, também, do capital intelectual de seus dirigentes e colaboradores, ou seja, o diferencial capaz de alavancar uma empresa para o sucesso encontra-se nas pessoas e no conhecimento que elas possuem. É, afinal, a gestão do conhecimento tão comentada nos dias atuais.

Uma vez que o administrador conheça as particularidades de seu país e do seu idioma, ele, com certeza, terá colaboradores capacitados e preocupados com a correta e adequada utilização da Língua Portuguesa em seu ambiente de trabalho e atuação, resultando uma imagem positiva, capaz de gerar lucros e aumentar a clientela. 


\section{BIBLIOGRAFIA}

ABAURRE, Maria Luíza; PONTARA, Marcela Nogueira; FADEL, Tatiana. Português: Língua e Literatura. São Paulo: Moderna, 2000.

CORRADO, Frank M. A força da comunicação: quem não se comunica. Tradução Bárbara Theoto Lambert. São Paulo: Makron Books, 1994.

MEDEIROS, João Bosco. Correspondência: técnicas de comunicação criativa. 9. ed. São Paulo: Atlas, 1995.

MORAES, Maria Cândida. O paradigma educacional emergente. 3. ed. Campinas, São Paulo: Papirus, 1999.

SANTOS, Eli Rozendo Moreira dos. Comunicação na pequena, média e grande empresa. Rio de Janeiro: Tecnoprint Ltda., 1980.

BRASIL. Seminário sobre a língua portuguesa: desafios e soluções. São Paulo, SP, 31 maio 1999. Disponível em: <http://www.academia.org.br/desafios.htm>. Acesso em: 18 abril 2002.

Jornal Diário do Pantanal. Campo Grande, MS, 25/26 maio 2002. Classificados: Seção Negócio Fechado, p. 39. 